\title{
Qualitative Analysis of Making Traditional Costumes, Weaving Crafts and Wood Sculptures - The Cultural Identity of Kalash Valley
}

\author{
Shumaila Islam ${ }^{1}$, Nadeem Afraz ${ }^{2 *}$ and Muhammad Arshad Rehmani ${ }^{3}$ \\ ${ }^{1}$ Principal author, lecturer, Institute of Art \& Design, The Sargodha University, Pakistan \\ ${ }^{2}$ Institute of Art \& Design, University of Sargodha-Pakistan \\ ${ }^{3}$ Visiting Lecturer, GC University, Faisalabad-Pakistan
}

Submission: November 11, 2020; Published: November 20, 2020

*Corresponding author: Nadeem Afraz, Institute of Art \& Design, University of Sargodha-Pakistan

\begin{abstract}
Cultures diversity represents the unique mindset and structure of human life. Various customs, traditions social dogmas and livelihoods trends weave the pattern of human activities. Kafiristan is one of such community that lays in valleys of Kalash in Chitral district in northern Pakistan. The inhabitants of Kalash valley practice their own peculiar religion, customs and that are reflected through their art of making traditional costumes, weaving Crafts and wood sculptures. All features of their traditions art making and customs are incomplete without each other. There is still a constant resistance against any social change and the inhabitants are trying to maintain and preserve their indigenous cultural identity. This paper is based on qualitative analysis with focuses on exploration of the distinct and intertwined features of making and using traditional costumes, weaving crafts and wood sculptures as cultural identity of the Kalash.
\end{abstract}

Keywords: Culture, Kalash, Chitral, traditional, costumes, Weaving crafts, Wood Sculptures, Cultural identity

\section{Introduction}

Many aspects of human life like belief, values, knowledge, taste, dress code, artistic expression, social conducts, and behaviors are associated with significance of culture. Particular kinds of characteristics that are mark of any cultural identity are owned through the living ways, conducts, and behaviors of a specific group of people. By practicing the peculiar customs and conventions, the specific groups of people adopt a different character and identity. Just because of individuality of living ways, the group make the personal identity prominent among other societies. Therefore, religion, art, and craft serve as the real image of a society because of being shared among individuals. Pakistan primarily a Muslim country was established in 1947 after cessation of colonial government, located in bastion of Indus valley. It is center of multicultural traditions and heritage. Being located in South Asia, it shares habitat, religious practices, languages, events and ethical commix with neighboring countries; accordingly, it is a bridge head to western and central Asian region. Major cultural ethnic groups of Pakistan are considered Sindhis, Punjabis, Pashtuns, Muhajirs, Baloch, Kashmiris, Brahuis, Saraikis, but there is one unique ethnic cultural group naming Kalash. It has maintained its individual personal identity among all the groups mentioned. The groups of inhabitants are living in Kalash valley located in the northern areas of Pakistan. The distinct ethnic group named Waigali or Wai and as 'Kafirs' are assumed to be originated from Dionysus (a Greek God) or Aryan descendants or perhaps evolved from the sons of the soldiers of Alexander the Great [1]. The people of this valley disclose their unique culture and customs through their peculiar religion, ways of living, rituals, and artistic heritage. The paper explores all these interweaved features; finds religion as a core entity from which all these elements are evolved, survived, and maintained their particular significance that is based on the concept of 'chastity and impurity'.

\section{Kalash culture: unique to pakistani identity}

In the valleys of Bumboret, Rumbor and Birir, the Kalash people also called Kafir (non-believer), black robe and siah posh live. In modern days, the area is called district of Chitral, Pakistan. The kalash is primeval tribe of Pakistan having their own identity, rituals, dialect and belief. The population of Kalash is 4,000 only estimated in year 2010 . The culture is unique that 
each year tourists, historians, anthropologists, sociologists and photographers come from all over the world to visit and observe its different and unique characteristics. The part is considered a well-preserved ethnic and cultural museum. Owing to this value, UNESCO has listed Kalash culture for consideration as World Heritage Site [2].

\section{Tradition of making Wood Sculptures}

Identity of a group is established by the traditions of the specific group. The key elements that allow tradition to transfer certain characteristics to a distinct group are religion, language, costumes, art and patterns. According to Malinowski's conclusions, the function of tribal religions is mainly with organizing, commemoration and helping people to adopt and perform events like birth, puberty, marriage and death [3]. The conventional wooden statues naming Gandao are erected by predecessor with a special goal to refresh the father's memoir as symbolic representation of diseased. These are erected on the grave of ancestors. Now rarely families are practicing the tradition. An anthropologist documented the tradition. According to him, Rehmat Wali was famous for making great wooden statues. He lived in Kalashgram town in Rumbur valley, which was once home to numerous wooden statues and kaundriks.

\section{i. A Kaundrik (triumphal post) in brun village bumboreth}

According to Rehmat Wali more than 40 Gandaos were situated in the surroundings of Rumbur valley, which were stolen by individuals to offer abroad. The stolen Gandaos that were associated with Khush Baig, Amir, Achayak, and Mahamurat and his 2 children were popular. Likewise, placed statue concerning Kushan Baig and Amir were also stolen. Because of continuous stealing sculptor left that tradition.

\section{ii. Gandaos}

One distinctive characteristic of the wooden sculptor was that he cut out model from one bit of wooden piece, which is allover difficult task. Such kind of strength is associated with Prasun and Bashgal valleys. The mounted Gandaos were made with wearing turbans, which was symbolism of force, boldness. One of artistic innovations was noticed that a Gandao without a turban or cap is found. The mouth of the figure had been hung open in awe. This reflects, according to the artist, the lost kingdom of the Kalash, who used to rule over all of Chitral. Gandao without headgear is a symbol of the loss of the Kalash's respect and power [1].

\section{Tradition of weaving and dress making}

As levi Strauss had been thought responsible for developing a materialistic and idealistic theory of symbolic representation and practices through clothing, so self-decoration, materialism and capitalism are the concepts that are associated with textiles as well. Similarly, as concern of Kalash female attire, it shows her attachment with her lifetime spent in valley, her companions and bondage with natal family. She is recognized and acknowledged as woman of home and her affections with husband.

\section{i. The Paran (Dress)}

The name given to Kalash specific female costume is Cou or Paran. The word Paran is derived from Parahan that means garments. This Kalash dress was made of deep dark black fabric and its style was called kimono. The women are habitual of wearing this dress in all seasons. This is prepared on handloom by weaving process and was handed over to youngsters at the age of three or four on Chilamjoshi festival. With the growing age, same dress is altered, and she is informed about significant importance of the costume. In past dress was decorated with metallic jewelry but recently use of colorful embroidery is noticed on neckline, sleeves and hemline. The use of colors is not restricted by the specific age. The formation of dress has similarities with Arabic style and has no resemblance with Greek ionic Chiton and draped dress.

\section{ii. Patti (belt)}

It is a simple belt for fastening around the waist for fixing dress and preventing it from losing the shape. The belt is designed with boarder and has fringes along with as decoration. The loose fabric of shirt is used as pockets for keeping small items like money, pins bands and fruits. The Patti is gifted to guests as well.

\section{iii. Susit (minor head dress)}

The minor headdress is a compulsory part of dress code for female and they are restricted to wear it all times when get outside. The headdress comprised on two parts: a ring and a long tail of approximately $10-15$ inches. This is presented as gift with Cou on her fourth birthday. It is symbolic representation of pride, honesty and reverence in the locality. Because their concept of integrity, pride and purity is attached to the dress so it is given to child after, ensuring its handling will be done with required grace and decency. The kalash women invest their precious time and effort to prepare dress. Old women as well as young take immense pleasure being beautiful not just for the festival, but for every day. It is observed that the females believe in conformity and are very proud of their attire, and do not wish to bring any change despite all the difficulties.

\section{iv. Kupas (The major head dress)}

The major headdress is the mark of Kalash recognition. The particular item that is difficult to carry but it provides shields from sun rays that is why it is considered very beneficial. Because of having formal feature, it is used on just ceremonies. Kupas are like scarf almost 20 inches long, 10 inches wide and heavily decorated with cowries, seashells, buttons and decorative stitches. The frontal side Kupa covers head and its long-tasseled tail hangs down back. These are placed on minor headdress susit that is not stitched or tied. The erect posture and balance maintained by female helps her to carry that. It is handed over to a girl at the age of 4 years. It also makes them prominent and is a mark of their 
individuality. The girls are prohibited to play with it otherwise result will be in danger of deities and they will curse them.

Kupas made on handloom are weaved arranging warp and weft yarn and, in the result, the plain weave is obtained. Warps are threads lengthwise that were fixed on loom holes and a twill weave pattern is acquired in a plain pattern. On the boarders, fringes are attached to decorate the Kupa. The cowries are fixed in seven lines and four lines for adults and child respectively. As the concern of size and number is, the more size and number is bigger the more respect, social statusand wealth is given to person in society. As the matter of designing on Kupas, females use two prominent designs. Shield design is inspiration from engravings on wall of temples and this is usually found on the Kupas for adults, whereas the second one design is used on youngsters and child Kupas comprise of floral arrangements of cowries. Their belief is associated with shield design because it will help them to be saved from evils, demons and bad luck. Furthermore, it is considered that mishandling by child will cause of trouble for them. The meaning and message that is linked with this design is that it reminds the memoirs of warriors and their heroic deeds. The arrangement of cowries' shells indicates the festival status of the honors ancestors. Rich girls can afford the Kupas embellished with cowries, whereas the average girl used buttons for decoration. The Kupas made for commercial purpose can be recognizable than to the one that is made for elite class. A cis that is a braided straw along with a colored feather enhance beauty and is a symbol of nobility.

\section{v. Male costumes}

Men's dress is common as of other areas and localities. They are supposed to wear Shalwar Kameez with waistcoat along with distinctive Chitrali cap. Males also used feather on their cap. Now a day's youngsters have followed fashion trends because of being aware of requirement of the time. Now they prefer to use jeans, pants with dress and t-shirt. The tradition of wearing waistcoat is replaced by the latest trend of jeans or leather jacket.

Following are the specific dresses that are supposed to be used by people during various occasions and events.

a) Ghuni Katohoki is a dress worn by the Shepherd in winter.

b) Ghuni Bhutis is a Shalwar made of goat hair stitched like a pant. It is a Shalwar like construction with ample gahir or gathers. The ankle girths are wound with as weaved kutapati.

c) Kutapati is a 4 to 6 inches weaved strip of identical to shaman (one they present as souvenir to honor the guest).

d) Shualak is a woolen dress. e) Danshak Bhut is a loosely draped woolen pant.

f) Khas'ong is a woolen cap used by the shepherd.

Cleanliness and hygiene are another noticeable point in their ways of living. They only use to take bath when their clothes are extremely dirty. As concern of their religious concept of cleanliness is, so that is depends on the principal of taking bath only on special occasions or events or on festivals. Their concept of purity and impurity is attached with their belief and they observe that belief all the time of their life at every events and occasion [4].

\section{Conclusion}

Peaceful living of Kalash is combination of their oral tradition, practical belief and religious system and conventional artistic cultural heritage. Due to its uniqueness peculiarity; they are successful to maintain their cultural individuality and identity. These are basic features that motivate them to feel need of recognition as distinctive community [5-7]. Not only by performing of rituals, but their belief is also reflected by the dress code of inhabitants, especially of female dress. The costume is considered symbol of respect and identity. For maintaining the requirement of this respect, they sustain the reasonable and proper handling of dress code by male and female both. Their whole life and culture are displayed and reflected through these dress codes, weaving crafts and Wood Sculptures. These are essence of their life and culture. Currently, the society is passing through phase of transition and transculturation because of media access to that area. People have adopted and inspired from latest trends, globalization and modernism specially youngsters, but still they are still trying preserve all the special, unique conventional heritage that is transferred them from their ancestor to safe their distinctive cultural identity.

\section{References}

1. Ali, Zulfiqar Kalhoro (2012) Art of Loss. The Friday Times 24: 26.

2. Ali, Kashif (2011) Kalasha: Definition. Ancient History Encyclopedia.

3. Kottak PC (2003) Cultural Anthropology. ( $8^{\text {th }}$ edn), McGraw-Hill.

4. Mohauddin Anwar, Irum Sheikh, Hafeez -Ur-Rehman Chaudhary (2014) Religion as a Space for Kalash Identity A Case Study of Village Bumburetin Kalash Valley, District Chitral, Pakistan 29(3): 426-432.

5. Derrett, Ros (2008) Regional Festivals: Nourishing Community Resilience: The Nature and Role of Cultural Festivals in Northern Rivers NSW Communities. Southern Cross University, Lisemore.

6. Wada, Akiko (2003) Kalasha: Their Life and Tradition. Sung_E_Meel Publication. Lahore, Pakistan.

7. (2019) Gull, Farhat, Saving Kalash velley, Heritage Friday Times. 
Your next submission with Juniper Publishers will reach you the below assets

- Quality Editorial service

- Swift Peer Review

- Reprints availability

- E-prints Service

- Manuscript Podcast for convenient understanding

- Global attainment for your research

- Manuscript accessibility in different formats

( Pdf, E-pub, Full Text, Audio)

- Unceasing customer service

Track the below URL for one-step submission https://juniperpublishers.com/online-submission.php 